\title{
Studies evaluating of health interventions at schools: an integrative literature review
}

\author{
Eliabe Rodrigues de Medeiros ${ }^{1}$ \\ Danielle Gonçalves da Cruz Rebouças ${ }^{2}$ \\ Alany Carla de Sousa Paiva ${ }^{3}$ \\ Camila Priscila Abdias do Nascimento ${ }^{4}$ \\ Sandy Yasmine Bezerra e Silva ${ }^{5}$ \\ Erika Simone Galvão Pinto ${ }^{6}$
}

Objective: to identify and analyze the available evidence on the strategies used in the studies evaluating health interventions at school. Method: this is an integrative review searching in LILACS, CINAHL, CUIDEN, ScienceDirect, and PubMed. From the pre-defined inclusion and exclusion criteria, there were 121 articles chosen to compose the sample. Results: english studies (97.5\%), with a quantitative approach (80.2\%), related to the interventions carried out in the Region of the Americas (54.6\%) and the European Region (23.1\%) predominated. For the most part, they are interventions as programs (70.2\%), interested in evaluating results $(73.5 \%)$ from the value judgment (83.4\%). Prevalence of interventions focused on efficacy, effects or impact, and activities carried out on interventions were focused on physical activity, healthy eating, sexual and reproductive health, mental health, and use of tobacco, alcohol, and other drugs. They are worked through activities of clinical monitoring, health promotion and disease prevention. Conclusion: the evidence indicates that the evaluations of health interventions in the school focus the results produced in programs through the judgment of value. The topics most addressed were healthy eating, physical activity, prevention of alcohol and other drugs, among others.

Descriptors: Health; Education; Health Services Research; School Health Services; Program Evaluation; Evaluation Studies.

${ }_{1}^{1}$ Doctoral student, Departamento de Enfermagem, Universidade Federal do Rio Grande do Norte, Natal, RN, Brazil. Bolsista do Conselho Nacional de Desenvolvimento Científico e Tecnológico (CNPq), Brazil.

2 Cardiology and Hemodynamics Specialist, Specialization student in Public Health: Oncology Nursing, Escola da Assembleia Legislativa do Rio Grande do Norte, Natal, RN, Brazil.

${ }^{3}$ Occupational Health Nursing Specialist, Specialization student in Higher Education Teaching, Escola de Saúde, Universidade Potiguar, Natal, RN, Brazil.

${ }^{4}$ Emergency and Trauma Nursing Specialist, Specialization student in Public Health, Faculdade de Saúde Pública, Universidade de São Paulo, São Paulo, SP, Brazil.

${ }_{5}^{5}$ Master's student, Departamento de Enfermagem, Universidade Federal do Rio Grande do Norte, Natal, RN, Brazil.

${ }^{6}$ PhD, Professor Adjunto, Departamento de Enfermagem, Universidade Federal do Rio Grande do Norte, Natal, RN, Brazil.

\section{How to cite this article}

Medeiros ER, Rebouças DGC, Paiva ACS, Nascimento CPA, Silva SYB, Pinto ESG. Studies evaluating of health interventions at schools: an integrative literature review. Rev. Latino-Am. Enfermagem. 2018;26:e3008. [Access $f$ 千 1 ]; Available in: DOI: http://dx.doi.org/10.1590/1518-8345.2463.3008. month day year 


\section{Introduction}

The offering of equal and equitable education across the globe has been one of the flags raised by international organizations in encouraging children and adolescents to be enrolled in schools. Also, it is also necessary to develop health interventions so these individuals do not have the educational process interrupted under the influence of diseases and other health problems ${ }^{(1)}$.

In these spaces, it is possible to contribute to the development of learners through interventions that subsidize educational success through the provision of care that may not be experienced at school. The lack of school health interventions together with the compromising situations (diseases and/or aggravations) prevalent in schools make the learning process difficult, where it is necessary to provide continuous care to the health of the children and adolescents in the school environment ${ }^{(2)}$.

In 1995, the World Health Organization (WHO) encouraged the development of the global strategy of Health Promoting Schools, characterized by the constant search to strengthen the capacity to promote a healthy life, with an incentive to learn and working conditions, to respond health needs of the school community(3).

Under this influence and based on the Ottawa Charter and as a result of the First International Conference on Health Promotion held in 1986, discussion groups were set up to encourage the development of health promotion strategies in school settings, such as the European Network of Health Promoting Schools and the Latin American Network of Health Promoting Schools ${ }^{(4)}$.

This fact contributed to creating several experiences all over the planet. However, because they are countries with diverse economic, political, cultural, and other contextual characteristics, it is necessary to consider that these interventions can be executed based on different objectives. Also, difficulties and challenges can be found in their implementations, requiring the need to develop evaluative processes that seek to improve them.

This is possible since the evaluation has been considered as an important tool to aid the management of health interventions in the search for better answers to services resulting from improvement, resolution and better quality ${ }^{(5)}$.

The evaluations of the health interventions at school have been carried out and involve specific topics such as prevention of depression and anxiety(6), the offering of physical activities to students(7) $^{(7)}$ and drug prevention among schoolchildren ${ }^{(8)}$. No studies have been found that synthesize comprehensively the evaluation of health interventions in school in the world and its different themes.

The purpose of this study is to synthesize the studies that carried out evaluations of health interventions at school, so their strategies and the diversity of interventions directed to this space can be identified. This will contribute to other research being carried out from the findings presented here.

The study advances knowledge as it presents the evidence on strategies used in evaluations of health interventions at school, enabling other health interventions at school to be evaluated as well.

Evaluations should be carried out by management and by health and education professionals to contribute to the promotion of health at school. It is observed by the activities developed in the daily life that the nurse performs interventions in the school environment in a continuous way.

The actions or health activities carried out in the school, such as policies, programs, projects, services, and systems, were considered an intervention. Evaluations are understood as the decision-making processes that aid in the improvement of the health interventions in the school. Therefore, there is an intimate relationship between the two, since it is not possible to evaluate interventions without knowing their organization.

In view of this information, the objective is to identify and analyze the available evidence on the strategies used in the evaluation studies of health interventions in the school.

\section{Method}

The integrative review of the literature was the methodological strategy chosen to respond to the proposed objective. It consists of a broad methodology of research analysis to synthesize knowledge about a given topic. The elaboration of a study of this nature runs through five stages: identification of the problem and elaboration of the guiding question; search for studies in the literature; evaluation of data found in the studies; data analysis with synthesis and their conclusions and the presentation of the integrative review ${ }^{(9)}$.

A protocol was built by the researchers to guide the construction of the study. The guiding question was elaborated with the help of the PICO strategy(10) ( $P$ : health interventions at school, I: evaluation studies, C: not applicable, O strategies used). What evidence is available about the strategies used in the evaluation studies of health interventions at school?

The search for the studies was carried out in May 2017 through the Portal of Journals of Capes with 
access through the Federated Academic Community (CAFe) in which the researchers are linked. The studies were selected in the electronic databases of Literatura Latino-Americana e do Caribe em Ciências da Saúde (LILACS), Cumulative Index to Nursing and Allied Health Literature (CINAHL), Base de Datos Bibliográfica de la Fundación Index (CUIDEN), ScienceDirect and US National Library of Medicine (PubMed).

To proceed with the search, descriptors in Health Sciences (DeCS) were used for the databases in Portuguese and Spanish and the corresponding Medical Subject Headings (MeSH), for the search in the electronic bases in English. The Boolean operators AND and OR were used to cross the descriptors as follows: "Serviços de Saúde Escolar AND Avaliação de Programas e Projetos de Saúde $O R$ Avaliação de Serviços de Saúde", "Servicios de Salud Escolar AND Evaluación de Programas y Proyectos de Salud OR Evaluación de Servicios de Salud" e "School Health Services AND Program Evaluation OR Health Services Research".

The inclusion criteria consisted of articles published in the last five years, available for free access in full in English, Spanish and Portuguese, which addressed the proposed theme. Editorials, letters to the editor, review studies, theses, dissertations, articles and studies that did not correspond to the relevant theme within the scope of the review were excluded.

The research and selection of the studies were carried out by two researchers, simultaneously. When a situation of divergence happened, a consensus was sought with the participation of an auxiliary researcher. The process of searching and selecting the studies followed the PRISMA recommendations ${ }^{(11)}$ and is represented in Figure 1.

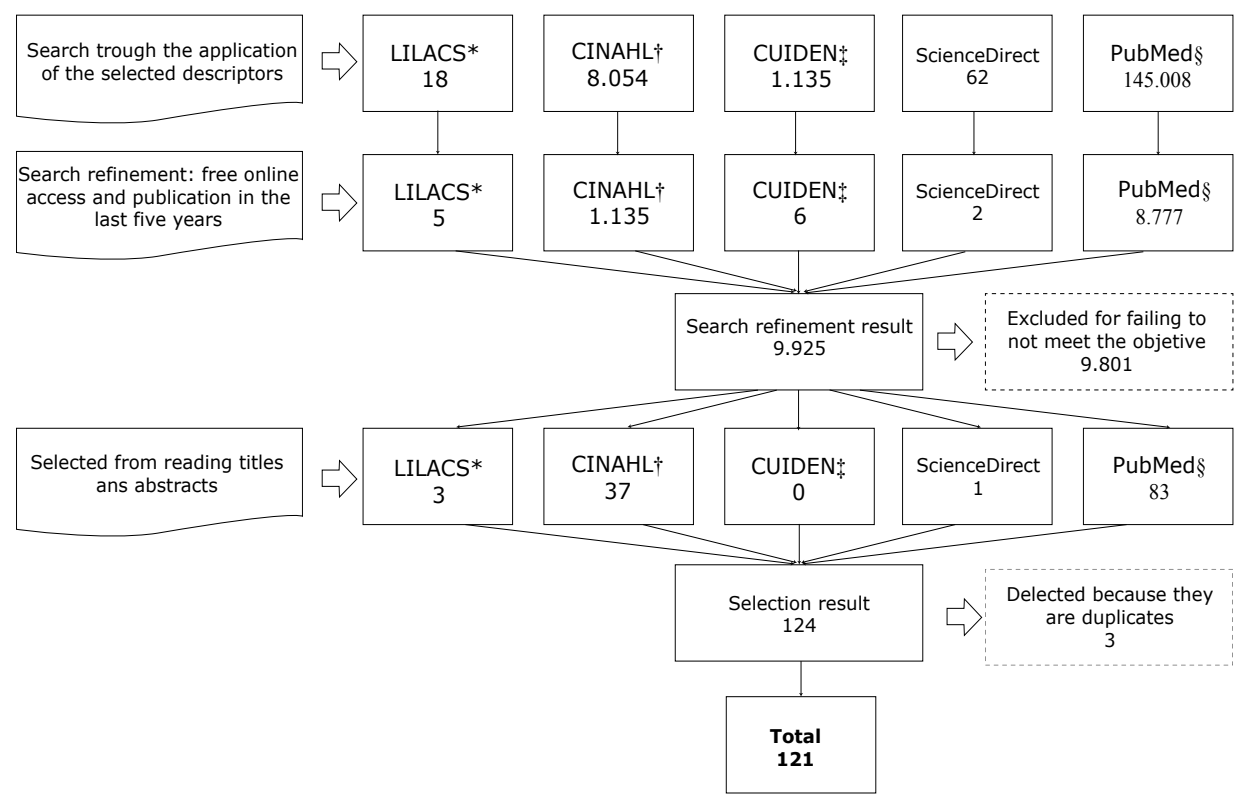

* LILACS: Literatura Latino-Americana e do Caribe em Ciências da Saúde

+ CINAHL: Cumulative Index to Nursing and Allied Health Literature

₹ CUIDEN: Base de Datos Bibliográfica de la Fundación Index

$\S$ PubMed: US National Library of Medicine

Figure 1 - Flowchart of identification of the selection process of the selected studies to compose the integrative review. Natal, RN, Brazil, 2017

The initial search in each database using the search term crossings was preceded by its refinement (free online access and publication in the last five years) in each of the electronic bases from the use of the available tools in the electronic portals. In the sequence, the titles and abstracts were read, making a quantitative of 124 studies in all the electronic bases. Also, repeated studies were excluded, where the final sample resulted in 121 articles.
The analysis of the selected studies was performed based on the pre-selected variables in the protocol construction. To organize them, a spreadsheet created in Microsoft Excel Software was used, containing the following items: database, journal, language, year of publication, methodological approach used, geographical location where the intervention was performed according to WHO classification, type (structure, 
process and outcome) according to Avedis Donabedian's theoretical reference ${ }^{(12)}$, level of evaluation (description, measurement, judgment, negotiation) according to the classification identified in Furtado's study ${ }^{(13)}$, type of evaluation, besides description of the themes and characteristics of the intervention.

The analysis and discussion of the results were based on the national and international literature on school health and health evaluation.

\section{Results}

The characterization of the selected studies ${ }^{(14-134)}$ included in the integrative review is presented below. In Table 1, information regarding the year and language of publication, the approach used in these surveys and the place of execution of the interventions are observed.

Table 1 - Characterization of the studies regarding the year, language, approach and place of intervention. Natal, RN, Brazil, 2017

\begin{tabular}{|c|c|c|}
\hline Variable & $\mathbf{N}^{*}$ & $\%^{\dagger}$ \\
\hline \multicolumn{3}{|l|}{ Year of publication } \\
\hline 2013 & 32 & 26.5 \\
\hline 2014 & 32 & 26.5 \\
\hline 2015 & 34 & 28.0 \\
\hline 2016 & 19 & 15.7 \\
\hline 2017 & 4 & 3.3 \\
\hline \multicolumn{3}{|l|}{ Language } \\
\hline English & 118 & 97.5 \\
\hline Spanish & 3 & 2.5 \\
\hline \multicolumn{3}{|l|}{ Type of research approach } \\
\hline Quantitative & 97 & 80.2 \\
\hline Qualitative & 10 & 8.2 \\
\hline Quantitative and Qualitative & 14 & 11.6 \\
\hline \multicolumn{3}{|l|}{ Regions of interventions } \\
\hline African Region & 5 & 4.1 \\
\hline Region of the Americas & 66 & 54.6 \\
\hline Southeast Asia Region & 7 & 5.8 \\
\hline European Region & 28 & 23.1 \\
\hline Eastern Mediterranean Region & 4 & 3.3 \\
\hline Western Pacific Region & 11 & 9.1 \\
\hline Total & 121 & 100.0 \\
\hline
\end{tabular}

*N: number; $\dagger \%$ : percentage

It should be noted that the lower percentage of studies published in 2017 is explained by the fact that the data collection was carried out with the year still in progress.
Information regarding the classification of the type of intervention, proposed evaluative dimension and level of evaluation performed are shown in Table 2.

Table 2 - Characterization of the studies regarding the type of intervention, dimension evaluated and level of evaluation performed. Natal, RN, Brazil, 2017

\begin{tabular}{|c|c|c|}
\hline Variable & $\mathbf{N}^{*}$ & $\%^{\dagger}$ \\
\hline \multicolumn{3}{|l|}{ Type of Intervention } \\
\hline Policy & 6 & 5.0 \\
\hline Program & 85 & 70.2 \\
\hline Project & 19 & 15.7 \\
\hline Service & 9 & 7.4 \\
\hline System & 2 & 1.7 \\
\hline \multicolumn{3}{|l|}{ Dimension evaluated } \\
\hline Structure & 2 & 1.7 \\
\hline Process & 24 & 19.8 \\
\hline Result & 89 & 73.5 \\
\hline Structure and Result & 2 & 1.7 \\
\hline Process and Result & 3 & 2.5 \\
\hline Structure, Process, and Result & 1 & 0.8 \\
\hline \multicolumn{3}{|l|}{ Level of Evaluation } \\
\hline Description & 11 & 9.1 \\
\hline Measure & 3 & 2.5 \\
\hline Judgment & 101 & 83.4 \\
\hline Negotiation & 6 & 5.0 \\
\hline Total & 121 & 100.0 \\
\hline
\end{tabular}

It was also possible to describe the interventions regarding the themes, characteristics, and typologies of evaluations proposed in their methodologies, as presented in Figure 2.

Thus, the data show that the evaluation of effects, efficacy, and impact was the most prevalent among the types of evaluation found.

It is observed that interventions of various themes have been carried out in the school environment, whether they are in a broader theme, such as activities that aim to encourage healthier lifestyles or more specific themes such as those that prevent accidents from occurring among learners.

These themes are worked with the school community through strategies that address the continuous clinical follow-up of learners $(25-26,30-31,46-47,63,74,98-95,108,132)$, through

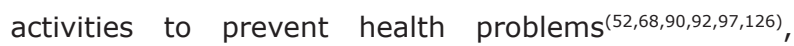
availability of resources in school spaces as a way of encouraging changes in habits(15,19,27,54,71,100,121-122,129), educational activities with students and other members of the school community $(14-24,27-29,32-45,49-51,53-62,64-67,69-73,75-77$, 79-89,91,93,98-107,109-125,127-131,133-134) and group activities ${ }^{(96)}$. 


\begin{tabular}{|c|}
\hline Types of evaluations \\
\hline 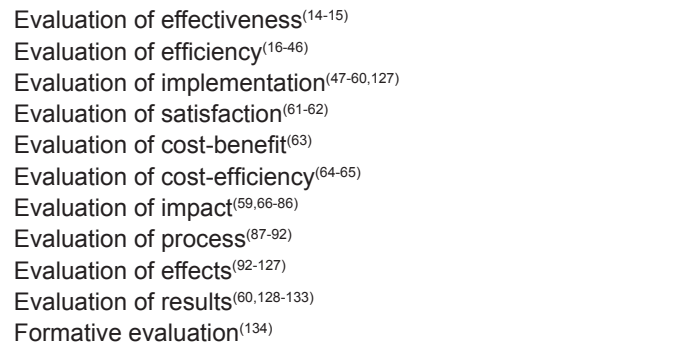 \\
\hline Themes of the interventions \\
\hline 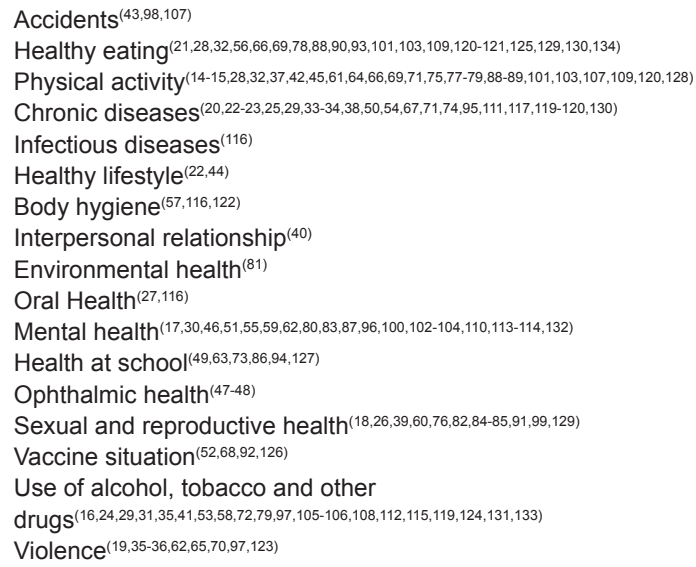 \\
\hline
\end{tabular}

Continuous clinical follow-up of students ${ }^{(25-26,30-31,46-47,63,74,78,94-95,108,132)}$

Health problems prevention activity $(52,68,90,92,97,126)$

Provision of resources ${ }^{(15,19,27,54,71,100,121-122,129)}$

Execution of educational activities with students,

teachers and parents or guardians of

students ${ }^{(14-24,27-29,32-45,49-51,53-62,64-67,69-73,75-77,79-89,91,93,98-107,109-125,127-131, ~ 133-134) ~}$

Promotion of group activities ${ }^{(96)}$

Figure 2 - Characterization of studies evaluating health interventions in school. Natal, RN, Brazil, 2017

\section{Discussion}

The high number of studies that integrated the integrative review shows the possible concern of the researchers in offering quality interventions in the school environment, which can be done when submitting them to the evaluation processes. However, a smaller number of publications were observed in the last two years of the analysis, which can be explained by the inclusion of a year still in progress during the review period.

The predominance of studies published in the English language reflects the fact that this is a widely disseminated language in the world. Therefore, it was considered by the scientific community as a universal language to contribute to the dissemination of publications in the world and to promote better $\operatorname{access}^{(135)}$.

When analyzing the types of approaches used in evaluative surveys of health interventions at school, it was identified that most of them used exclusively the quantitative approach. In contrast, there were studies that proposed qualitative analysis. However, this type of research requires the appropriation of several means to understand the problems, which is possible with the integration of these two types of approaches(136).

The observation that there was a greater predominance of studies published in the Region of the Americas, mainly in the United States of America, and in the European Region, shows the understanding that the largest world economic powers are located there, and can consequently have greater investments in the execution of searches. In contrast, the regions in which the nations with the lowest human development indicators are found are also those with a reduced number of health interventions in school.

According to the classification of the interventions proposed for analysis, it was identified that most of them refer to programs to improve students' health. On the other hand, there is a discrete presence of interventions classified as systems that offer the search for health care to learners.

Prevalently, it was identified that most evaluative research sought to carry out evaluations focusing on the results of the interventions. It is important to emphasize the need to consider the development of these evaluations so they do not only focus on the presence or absence of the results brought about by the intervention, but also try to understand the factors that influenced the process ${ }^{(137)}$. It is also considered that, although studies are usually found that deal with outcome evaluations, the structure and process can influence the presentation of what is expected of these interventions ${ }^{(12)}$. Therefore, it is important to emphasize the equal importance of these dimensions in proposals for the execution of activities directed at school spaces.

Considering the level of evaluation of the research carried out, a large number of studies with an evaluation at the judgment level were found. Thus, evaluations of health interventions at school exceeded descriptive and measurement evaluations when judging value. However, there is still a small number of evaluations that propose a process of negotiation between those involved in the school environment ${ }^{(138)}$.

Thus, although the nomenclatures attributed to the evaluations are diversified, they can be performed identically. Nevertheless, it is noted that these types of proposed evaluations aim for interventions to perform the search for better results ${ }^{(139)}$.

The evaluations found may also influence the evaluation levels identified from the historical generations. Thus, in its first generation, the evaluations were descriptive. In the second generation of evaluations, there was research that sought to measure performance. The third generation has evaluations that 
try to judge the merits of the interventions. In the fourth generation, there is an evaluation that advocates the participatory negotiation process among the different participants in the intervention ${ }^{(13)}$.

The fourth-generation evaluation can be carried out in school health interventions, since they have activities that allow the participation not only of the students but also of teachers, other school workers, health professionals, parents or responsible for the students in their proposals, as well as representatives of the community in which the schools are inserted(140).

Regarding the themes in which these interventions were proposed, similar results were observed in a study carried out in the United Kingdom on the structures of the World Health Promoting Schools ${ }^{(141)}$. The following themes of interventions prevailed: physical activities, healthy eating, sexual and reproductive health, mental health and tobacco use, alcohol and other drugs.

As for the characteristics of these interventions, it was found that besides to continuous follow-up of students, preventive activities, health promotion with the school community and use of talk circles, there is the availability of resources to encourage a change of habits. This last characteristic corroborates with a research carried out in Canada, which refers to the presence of objects and food to encouraging the promotion of healthy eating and physical activities ${ }^{(142)}$.

The diversity of the themes and the characteristics related to health interventions at the school evaluated is essential in changing habits for the life of the students and the community where they live. This is identified in a study that shows that, these activities are of great importance to the health of the population although they seem small actions in face of the diversity of needs found ${ }^{(141)}$.

It should be emphasized that the limitations of this research were related to the high number of studies eligible for an integrative review, although the criteria chosen were delimited. Also, it is observed that the use of more than one researcher for data analysis may influence the presented results, although they were able to perform this activity.

\section{Conclusions}

The evidence found in the studies show that school health programs are the most commonly evaluated interventions, especially at the value judgment level. These studies are mainly focused on evaluating the results produced by the interventions, corroborated in the typologies of impact, effects, efficacy, and results.

The themes of the studies are related to healthy eating, physical activity, mental, sexual and reproductive health, as well as prevention of the consumption of alcohol, crack and other drugs. They are implemented through strategies of continuous clinical monitoring, health promotion, disease prevention and health problems, and group activities involving students and other members of the school community.

\section{References}

1. United Nations Educational, Scientific and Cultural Organization. Reducing global poverty through universal primary and secondary education. UNESCO. [Internet]. 2017 Jun [cited Jul 2, 2017];32(44):1-16. Available from: http://unesdoc.unesco.org/ images/0025/002503/250392E.pdf

2. Chidiebere ODI, Thomas UO, Joy E, Stanley OK, Ikenna NK, Uchenna E, et al. The Status of School Health Services: A Comparative Study of Primary Schools in a Developing Country. Am J Public Health Res. 2016;4(2):42-6. doi: http://dx.doi.org/10.12691/ajphr-4-2-1

3. World Health Organization. Health Promoting School: an effective approach for early action on NCD risk factors. WHO. [Internet]. 2017 [cited Jul 2, 2017]. Available from: http://apps.who.int/iris/bitstream/10665/255625/1/ WHO-NMH-PND-17.3-eng.pdf?ua $=1$

4. Silva CS, Bodstein RCA. A theoretical framework on intersectoral practice in School Health Promotion. Cienc Saúde Coletiva. 2016 Jun; 21(6):1777-88. doi: http://dx.doi.org/10.1590/1413-81232015216.08522016 5. Tanaka OY, Drumond M Jr, Cristo EB, Spedo SM, Pinto NRS. Cluster analysis as a tool for management improvement in the SUS. Saúde Soc. [Internet]. 2015 Mar [cited Jul 14, 2017];24(1):34-45. doi: http://dx.doi.org/10.1590/S0104-12902015000100003

6. Werner-Seidler A, Perry Y, Calear AL, Newby JM, Christensen $H$. School-based depression and anxiety prevention programsforyoung people: Asystematicreview and meta-analysis. Clin Psychol Rev. 2017 Feb; 51:30-47. doi: https://doi.org/10.1016/j.cpr.2016.10.005

7. Mei H, Xiong Y, Xie S, Guo S, Li Y, Guo B, et al. The impact of long-term school-based physical activity interventions on body mass index of primary school children - a meta-analysis of randomized controlled trials. BMC Public Health. 2016; 16:205. doi: http://dx.doi.org/10.1186/s12889-016-2829-z

8. Flynn $A B$, Falco $M$, Hocini $S$. Independent Evaluation of Middle School-Based Drug Prevention Curricula A Systematic Review. JAMA Pediatr. 2015 Nov; 169(11):1046-52. doi: http://dx.doi.org/10.1001/jamapediatrics.2015.1736 9. Hopia H, Latvala E, Liimatainen L. Reviewing the methodology of an integrative review. Scand J Caring Sci. [Internet]. 2016 Dec [cited Jul 14, 2017];30(4):662-9. 
Available from: http://onlinelibrary.wiley.com/doi/ 10.1111/scs.12327/epdf

10. Santos CMC, Pimenta CAM, Nobre MRC. The PICO strategy for the research question construction and evidence search. Rev. LatinoAm. Enfermagem. 2007 Jun; 15(3):508-11. doi: http://dx.doi.org/10.1590/S0104-11692007000300023 11. Moher D, Liberati A, Tetzlaff J, Altman DG, The PRISMA Group. Preferred Reporting Items for Systematic Reviews and Meta-Analyses: The PRISMA Statement. PLoS Med. 2009 Jul; 6(7):e1000097. doi: https://doi.org/10.1371/journal.pmed.1000097

12. Donabedian A. Evaluating the Quality of Medical Care. Milbank Q. [Internet]. 2005 [cited Jul 3, 2017];83(4):691-729. Available from: https://www.ncbi.nlm.nih.gov/pmc/articles/PMC2690293/ pdf/milq0083-0397.pdf

13. Furtado JP. A Constructivist method for health evaluation. Cienc Saúde Coletiva. 2001 Jan-Jun; 6(1):165-81. doi: http://dx.doi.org/10.1590/S1413-81232001000100014

14. Seo DC, King MH, Kin N, Sovinski D, Meade R, Lederer AM. Predictors for moderate- and vigorous-intensity physical activity during an 18-month coordinated school health intervention. Prev Med. 2013; 57(5):466-70. doi: http://dx.doi.org/10.1016/j.ypmed.2013.06.024

15. Cradock AL, Barrett JL, Carter J, McHugh A, Sproul J, Russo ET, et al. Impact of the Boston Active School Day policy to promote physical activity among children. Am J Health Promot. 2014 Jan-Feb; 28(3 Suppl):S54-64. doi: http://dx.doi.org/10.4278/ajhp.130430-QUAN-204 16. TurhanA, OnrustSA, KloosterPM, PieterseME. Aschoolbased programme for tabacco and alcohol prevention in special education: effectiveness of the modified 'healthy school and drugs' intervention and moderation by school subtype. Addiction. 2017; 112(3):533-43. doi: http://dx.doi.org/10.1111/add.13672

17. Onge JRS, Stephenson R, Kumar BS. Validation of the FRIENDS Anxiety Prevention Program for Children in Canada. Can J Commun Ment Health. 2016; 35(3):25-40. doi: https://doi.org/10.7870/cjcmh-2016-036

18. Loosier PS, Doll S, Lepar D, Ward K, Gamble G, Dittus PJ. Effectiveness of an Adaptation of the Project Connect Health Systems Intervention: Youth and ClinicLevel Findings. J Sch Health. 2016 Aug; 86(8):595-603. doi: http://dx.doi.org/10.1111/josh.12414

19. Avci D, Kelleci M. Effects of the Anger Coping Programme based on cognitive behavioural techniques on adolescents' anger, aggression and psychological symptoms. Int J Nurs Pract. 2016 Apr; 22(2):189-96. doi: http://dx.doi.org/10.1111/ijn.12410

20. Lwin MO, Malik S, Chua TSJ, Chee TS, Tan YS. Intergenerational transfer of blood pressure knowledge and screening: a school-based hypertension awareness program in Singapore. Glob Health Promot. 2016 Mar; 23(1):27-36. doi: http://dx.doi.org/10.1177/1757975914555730

21. Zhou WJ, Xu XL, Li G, Sharma M, Qie YL, Zhao $Y$. Effectiveness of a school-based nutrition and food safety education program among primary and junior high school students in Chongqing, China. Glob Health Promot. 2016 Mar; 23(1):37-49. doi: https://doi.org/10.1177/1757975914552914

22. Bhave S, Pandit A, Yeravdekar R, Madkaikar V, Chinchwade T, Shaikh N, et al. Effectiveness of a 5-year school-based intervention programme to reduce adiposity and improve fitness and lifestyle in Indian children; the SYM-KEM study. Arch Dis Child. 2016 Jan; 101(1):33-41. doi: http://dx.doi.org/10.1136/archdischild-2015-308673 23. Tatsuo A, Chiaki Y, Yuki S, Yuya S, Yasuteru I, Akiko I, et al. Stroke Education Program of Act FAST for Junior High School Students and Their Parents. J Stroke Cerebrovasc Dis. 2014 May-Jun; 23(5):1040-5. doi: http://dx.doi.org/10.1016/j.jstrokecerebrovasdis.2013.08.021 24. Giuseppe G, Giulia C, Sandra B, Marco T, Claudia $M$, Simone $S$, et al. Effectiveness of a school-based multi-component smoking prevention intervention: The LdP cluster randomized controlled trial. Prev Med. 2014 Apr; 61:6-13. doi: https://doi.org/10.1016/j.ypmed.2014.01.004

25. Rito AI, Carvalho MA, Ramos C, Breda J. Program Obesity Zero (POZ) - a communitybased intervention to address overweight primaryschool children from five Portuguese municipalities. Public Health Nutr. 2013 Jun; 16(6):1043-51. doi: http://dx.doi.org/10.1017/S1368980013000244

26. Griswold $\mathrm{CH}$, Nasso JT, Swider S, Ellison BR, Griswold DL, Brooks M. The Prenatal Care at School Program. J Sch Health. 2013 Jun; 29(3):196-203. doi: http://dx.doi.org/10.1177/1059840512466111

27. Matsuyama Y, Aida J, Taura K, Kimoto K, Ando Y, Aoyama $H$, et al. School-Based Fluoride Mouth-Rinse Program Dissemination Associated With Decreasing Dental Caries Inequalities Between Japanese Prefectures: An Ecological Study. J Epidemiol. 2016 Nov; 26(11):563-71. doi: http://dx.doi.org/10.2188/jea.JE20150255

28. Maatoug J, Msakni Z, Zammit N, Bhiri S, Harrabi I, Boughammoura $L$, et al. School-Based Intervention as a Component of a Comprehensive Community Program for Overweight and Obesity Prevention, Sousse, Tunisia, 2009-2014. Prev Chronic Dis. 2015 Sep; 12:e160. doi: http://dx.doi.org/10.5888/pcd12.140518

29. Brinker TJ, Stamm-Balderjahn S, Seeger W, Klingelhöfer D, Groneberg DA. Education Against Tobacco (EAT): a quasi-experimental prospective evaluation of a multinational medical-student-delivered smoking prevention programme for secondary schools 
in Germany. BMJ Open. 2015; 5(9):e008093. doi: http://dx.doi.org/10.1136/bmjopen-2015-008093

30. Langley AK, Gonzalez A, Sugar CA, Solis D, Jaycox L. Bounce back: Effectiveness of an elementary school-based intervention for multicultural children exposed to traumatic events. J Consult Clin Psychol. 2015; 83(5):853-65. doi: http://x.doi.org/10.1037/ccp0000051

31. Strøm HK, Adolfsen F, Handegård BH, Natvig $H$, Eisemann M, Martinussen $M$, et al. Preventing alcohol use with a universal school-based intervention: results from an effectiveness study. BMC Public Health. 2015; 15:337. oi: http://dx.doi.org/10.1186/s12889-015-1704-7

32. Kilanowski JF, Gordon NH. Making a Difference in Migrant Summer School: Testing a Healthy Weight Intervention. Public Health Nurs. 2015; 32(5):421-9. doi: http://dx.doi.org/10.1111/phn.12175

33. Kintner EK, Cook G, Marti CN, Allen A, Stoddard D, Harmon $P$, et al. Effectiveness of a school- and communitybased academic asthma health education program on use of effective asthma self-care behaviors in older schoolage students. J Spec Pediatr Nurs. 2015; 20(1):62-75. doi: http://dx.doi.org/10.1111/jspn.12099

34. Kintner EK, Cook G, Marti CN, Gomes M, Meeder L, Van Egeren LA. Effectiveness of a schoolbased academic asthma health education and counseling program on fostering acceptance of asthma in older school-age students with asthma. J Spec Pediatr Nurs. 2015; 20(1):49-61. doi: http://dx.doi.org/10.1111/jspn.12098

35. Nieri T, Apkarian J, Kulis S, Marsiglia FF. Effects of a youth substance use prevention program on stealing, fighting, and weapon use. J Prim Prev. 2015; 36(1):41-9. doi: http://dx.doi.org/10.1007/s10935-014-0373-0

36. Thakore RV, Apfeld JC, Johnson RK, Sathiyakumar V, Jahangir AA, Sethi MK. Schoolbased violence prevention strategy: a pilot evaluation. J Inj Violence Res. 2015; 7(2):45-53. doi: http://dx.doi.org/10.5249/jivr.v7i2.565

37. Vander Ploeg KA, Maximova K, McGavock J, Davis W, Veugelers P. Do school-based physical activity interventions increase or reduce inequalities in health? Soc Sci Med. 2014; 112:80-7. doi: http://dx.doi.org/10.1016/j.socscimed.2014.04.032

38. Stölzel F, Seidel N, Uhmann S, Baumann M, Berth $\mathrm{H}$, Hoyer J, et al. Be smart against cancer! A school-based program covering cancer-related risk behavior. BMC Public Health. 2014; 14:392. doi: http://dx.doi.org/10.1186/1471-2458-14-392

39. Wang B, Deveaux L, Knowles V, Koci V, Rolle G, Lunn $S$, et al. Fidelity of implementation of an evidencebased HIV prevention program among Bahamian sixth grade students. Prev Sci. 2015; 16(1):110-21. doi: http://dx.doi.org/10.1007/s11121-014-0486-y

40. McNaughton DB, Cowell JM, Fogg L. Efficacy of a Latino mother-child communication intervention in elementary schools. J Sch Nurs. 2014; 31(2):126-34. doi: http://dx.doi.org/10.1177/1059840514526997

41. Pettigrew J, Graham JW, Miller-Day M, Hecht $\mathrm{ML}$, Krieger JL, Shin YJ. Adherence and delivery: implementation quality and program outcomes for the seventh-grade keepin' it REAL program. Prev Sci. 2015;16(1):90-9. doi: http://dx.doi.org/10.1007/ s11121-014-0459-1

42. Vander Ploeg KA, McGavock J, Maximova $\mathrm{K}$, Veugelers PJ. School-based health promotion and physical activity during and after school hours. Pediatrics. 2014; 133(2):e371-8. doi: http://dx.doi.org/10.1542/peds.2013-2383

43. Cao ZJ, Chen Y, Wang SM. Health belief model based evaluation of school health education programme for injury prevention among high school students in the community context. BMC Public Health. 2014; 14:26. doi: http://dx.doi.org/10.1186/1471-2458-14-26

44. Peñalvo JL, Sotos-Prieto M, Santos-Beneit G, Pocock S, Redondo J, Fuster V. The Program SI! intervention for enhancing a healthy lifestyle in preschoolers: first results from a cluster randomized trial. BMC Public Health. 2013; 13:1208. doi: http://dx.doi.org/10.1186/1471-2458-13-1208

45. D'Haese S, Van Dyck D, De Bourdeaudhuij I, Cardon G. Effectiveness and feasibility of lowering playground density during recess to promote physical activity and decrease sedentary time at primary school. BMC Public Health. 2013; 13:1154. doi: http://dx.doi.org/10.1186/1471-2458-13-1154

46. George MW, Trumpeter NN, Wilson DK, McDaniel $\mathrm{HL}$, Schiele B, Prinz R, et al. Feasibility and preliminary outcomes from a pilot study of an integrated healthmental health promotion program in school mental health services. Fam Comm Health. 2014; 37(1):19-30. doi: http://dx.doi.org/10.1097/FCH.0000000000000012

47. Johnson C, Majzoub K, Lyons S, Martirosyan K, Tattersall P. Eyes That Thrive in School: A Program to Support Vision Treatment Plans at School. J Sch Health. 2016; 86(5):391-6. doi: http://dx.doi.org/10.1111/josh.12387

48. Hobday K, Ramke J, du Toit R, Pereira SM. Healthy Eyes in Schools: An evaluation of a school and community-based intervention to promote eye health in rural Timor-Leste. Health Educ J. 2015; 74(4):392-402. doi: https://doi.org/10.1177/0017896914540896

49. Liao LL, Liu CH, Chang FC, Cheng CCJ, Niu YZ, Chang TC. Evaluation of the Health-Promoting School Supporting Network in Taiwan. J Sch Health. 2015; 85(7):487-95. doi: http://dx.doi.org/10.1111/josh.12275 
50. Totura CM, Figueroa HL, Wharton C, Marsiglia FF. Assessing implementation of evidencebased childhood obesity prevention strategies in schools. Prev Med Rep. 2015; 2:347-54. doi: http://dx.doi.org/10.1016/j.pmedr.2015.04.008

51. Flynn A, Zackula R, Klaus NM, McGinness L, Carr S, Macaluso M. Student Evaluation of the Yellow Ribbon Suicide Prevention Program in Midwest Schools. Prim Care Companion CNS Disord. 2016; 18(3). doi: http://dx.doi.org/10.4088/PCC.15m01852

52. Moodley N, Gray G, Bertram M. Projected economic evaluation of the national implementation of a hypothetical HIV vaccination program among adolescents in South Africa, 2012. BMC Public Health. 2016; 16:330. doi: https://doi.org/10.1186/s12889-016-2959-3

53. Medeiros PF, Cruz JI, R Schneider D, Sanudo A, Sanchez ZM. Process evaluation of the implementation of the Unplugged Program for drug use prevention in Brazilian schools. Subst Abuse Treat Prev Policy. 2016; 11:2. doi: http://dx.doi.org/10.1186/s13011-015-0047-9

54. Safdie M, Cargo M, Richard L, Lévesque L. An ecological and theoretical deconstruction of a school-based obesity prevention program in Mexico. Int J Behav Nutr Phys Act. 2014; 11:103. doi: https://doi.org/10.1186/s12966-014-0103-2

55. Garmy P, Jakobsson U, Carlsson KS, Berg A, Clausson EK. Evaluation of a school-based program aimed at preventing depressive symptoms in adolescents. J Sch Nurs. 2015; 31(2):117-25. doi: https://doi.org/10.1177/1059840514523296

56. Volpe SL, Hall WJ, Steckler A, Schneider M, Thompson $D$, Mobley $C$, et al. Process evaluation results from the healthy nutrition intervention to modify the total school food environment. Health Educ Res. 2013; 28(6):970-8. doi: https://doi.org/10.1093/her/cyt096

57. Chittleborough CR, Nicholson AL, Young E, Bell $\mathrm{S}$, Campbell R. Implementation of an educational intervention to improve hand washing in primary schools: process evaluation within a randomised controlled trial. BMC Public Health. 2013; 13(757). doi: https://doi.org/10.1186/1471-2458-13-757

58. Tahlil T, Coveney J, Woodman RJ, Ward PR. Exploring recommendations for an effective smoking prevention program for indonesian adolescents. Asian Pac J Cancer Prev. 2013; 14(2):865-871. doi: https://doi.org/10.7314/APJCP.2013.14.2.865

59. Clarke AM, Bunting B, Barry MM. Evaluating the implementation of a school-based emotional well-being programme: a cluster randomized controlled trial of Zippy's Friends for children in disadvantaged primary schools. Health Educ Res. 2014; 29(5):786-98. doi: https://doi.org/10.1093/her/cyu047
60. Bonita S, Wang B, Deveaux L, Lunn S, Rolle G, Mortimer A, et al. Teachers' Patterns of Implementation of an Evidence-Based Intervention and Their Impact on Student Outcomes: Results from a Nationwide Dissemination over 24-Months Follow-Up. AIDS Behav. 2015; 19(10):1828-40. doi: https://doi.org/10.1007/s10461-015-1110-2

61. DinkelDM, Huberty J, Beets MW. Qualitative Evaluation of GoGirlGo! Insights From Staff on Using a Curriculum Within After-School Programs to Improve Physical Activity. Health Promot Pract. 2015; 16(2):184-92. doi: https://doi.org/10.1177/1524839914555571

62. Černi OE, Zadro K, Batić-Mujanović O, Zalihić A. Satisfaction with the program of school bullying prevention and mental health promotion - cross sectional study among primary school pupils in Mostar. Acta Med Acad. 2013; 43(1):35-9. doi: https://doi.org/10.5644/ama2006-124.98

63. Wang LY, Vernon-Smiley M, Gapinski MA, Desisto M, Maughan E, Sheetz A. Cost-benefit study of school nursing services. JAMA Pediatr. 2014; 168(7):642-8. doi: https://doi.org/10.1001/jamapediatrics.2013.5441 64. Wang H, Li T, Siahpush M, Chen LW, Huberty J. CostEffectiveness of Ready for Recess to Promote Physical Activity in Children. J Sch Health. 2017; 87(4):278-85. doi: https://doi.org/10.1111/josh.12495

65. Barron IG, Topping KJ. Exploratory Evaluation of a School-Based Child Sexual Abuse Prevention Program. J Child Sex Abus. 2013; 22(8):931-48. doi: https://doi.org/10.1080/10538712.2013.841788

66. Safdie $M$, Jennings-Aburto $N$, Lévesque $L$, Janssen I, Campirano-Núñez F, López-Olmedo N, et al. Impact of a school-based intervention program on obesity risk factors in Mexican children. Salud Publica Mex. [Internet]. 2013 [cited Jul 20, 2017];55(3):37487. Available from: http://www.scielosp.org/ pdf/spm/v55s3/v55s3a4.pdf

67. Velsor-Friedrich $B$, Richards $M$, Militello LK, Dean KC, Scott D, Gross IM, et al. The Impact of Community Violence on School-Based Research. J Sch Nurs. 2015; 31(6):397-401. doi: https://doi.org/10.1177/1059840515605362

68. Plaspohl SS, Dixon BT, Streater JA, Hausauer ET, NewmanCP, VogelRL. ImpactofSchoolFlu VaccineProgram on Student Absences. J Sch Nurs. 2013; 30(1):75-80. doi: https://doi.org/10.1177/1059840513487750

69. McIsaac JL, Chu YL, Blanchard C, Rossiter M, Williams $P$, Raine $K$, et al. The impact of school policies and practices on students' diets, physical activity levels and body weights: A province-wide practicebased evaluation. Can J Public Health. 2015; 106(2):e43-51. doi: https://doi.org/10.17269/cjph.106.4743 
70. Espelage DL, Low S, Polanin JR, Brown EC. The impact of a middle school program to reduce aggression, victimization, and sexual violence. J Adolesc Health. 2013; 53(2):180-6. doi: https://doi.org/10.1016/j.jadohealth.2013.02.021

71. Lubans DR, Smith JJ, Plotnikoff RC, Dally KA, Okely $A D$, Salmon J, et al. Assessing the sustained impact of a school-based obesity prevention program for adolescent boys: the ATLAS cluster randomized controlled trial. Int J Behav Nutr Phys Act. 2016;13:92. doi: https://doi. org/10.1186/s12966-016-0420-8

72. Tomczyk S, Hanewinkel R, Isensee B. 'Klar bleiben': a school-based alcohol prevention programme for German adolescents-study protocol for a cluster randomised controlled trial. BMJ Open. 2015; 5(11):e010141. doi: https://doi.org/10.1136/bmjopen-2015-010141

73. Melnyk BM, Jacobson D, Kelly SA, Belyea MJ, Shaibi GQ, Small $L$, et al. Twelve-Month Effects of the COPE Healthy Lifestyles TEEN Program on Overweight and Depressive Symptoms in High School Adolescents. J Sch Health. 2015; 85(12):861-70. doi: https://doi.org/10.1111/josh.12342

74. Corriveau N, Eagle T, Jiang Q, Rogers R, Gurm $\mathrm{R}$, Aaronson $\mathrm{S}$, et al. Sustained Benefit Over FourYear Follow-Up of Michigan's Project Healthy Schools. Am J Public Health. 2015; 105(12):e19-e25. doi: https://doi.org/10.2105/AJPH.2015.302835

75. Thompson HR, Vittinghoff E, Linchey JK, Madsen $\mathrm{KA}$. Public Disclosure to Improve Physical Education in an Urban School District: Results From a 2-Year QuasiExperimental Study. J Sch Health. 2015; 85(9):604-10. doi: https://doi.org/10.1111/josh.12286

76. Mathews C, Eggers SM, de Vries PJ, MasonJones AJ, Townsend L, Aarø LE, et al. Reaching the hard to reach: longitudinal investigation of adolescents' attendance at an after-school sexual and reproductive health programme in Western Cape, South Africa. BMC Public Health. 2015; 15:608. doi: https://doi.org/10.1186/s12889-015-1963-3

77. Beets MW, Weaver RG, Turner-McGrievy G, Huberty J, WardDS, PateRR, etal. Making policy practice in afterschool programs: a randomized controlled trial on physical activity changes. Am J Prev Med. 2015; 48(6):694-706. doi: https://doi.org/10.1016/j.amepre.2015.01.012

78. Madsen KA, Cotterman C, Crawford P, Stevelos J, Archibald A. Effect of the Healthy Schools Program on prevalence of overweight and obesity in California schools, 2006-2012. Prev Chronic Dis. 2015; 12:e77. doi: https://doi.org/10.5888/pcd12.150020

79. Trigwell J, McGee CE, Murphy RC, Porcellato LA, Ussher M, Garnham-Lee K, et al. Process evaluation of a sport-for-health intervention to prevent smoking amongst primary school children:
SmokeFree Sports. BMC Public Health. 2015; 15:347. doi: https://doi.org/10.1186/s12889-015-1645-1

80. Wing YK, Chan NY, Man Yu MW, Lam SP, Zhang J, Li SX, et al. A school-based sleep education program for adolescents: a cluster randomized trial. Pediatrics. 2015; 135(3):e635-43. doi: https://doi.org/10.1542/peds.2014-2419

81. Guidry VT, Lowman A, Hall D, Baron D, Wing S. Challenges and benefits of conducting environmental justice research in a school setting. New Solut. 2014; 24(2):153-70. doi: https://doi.org/10.2190/NS.24.2

82. Charafeddine L, Rafei RE, Azizi S, Sinno D, Alamiddine $\mathrm{K}$, Howson $\mathrm{CP}$, et al. Improving awareness of preconception health among adolescents: experience of a school-based intervention in Lebanon. BMC Public Health. 2014; 14:774. doi: https://doi.org/10.1186/1471-2458-14-774

83. Shochet I, Montague R, Smith C, Dadds M. A qualitative investigation of adolescents' perceived mechanisms of change from a universal schoolbased depression prevention program. Int J Environ Res Public Health. 2014; 11(5):5541-54. doi: https://doi.org/10.3390/ijerph110505541

84. Kaufman CE, Whitesell NR, Keane EM, Desserich JA, Giago C, Sam A, et al. Effectiveness of Circle of Life, an HIV-preventive intervention for American Indian middle school youths: a group randomized trial in a Northern Plains tribe. Am J Public Health. 2014; 104(6):e106-12. doi: https://doi.org/10.2105/AJPH.2013.301822

85. Jennings JM, Howard S, Perotte CL. Effects of a school-based sexuality education program on peer educators: the Teen PEP model. Health Educ Res. 2014; 29(2):319-29. doi: https://doi.org/10.1093/her/cyt153 86. Takeuchi R, Boureima D, Mizuguchi D, Awazawa $T$, Kato $Y$, Akiyama $T$, et al. Self-assessed approach to improving school health in Niger. Rural Remote Health. [Internet]. 2013 [cited Jul 29, 2017];13(3):2354. Available from: http://www.rrh.org.au/publishedarticles/ article_print_2354.pdf

87. Demissie Z, Brener N. Demographic Differences in District-Level Policies Related to School Mental Health and Social Services-United States, 2012. J Sch Health. 2017; 87(4):227-35. doi: https://doi.org/10.1111/josh.12489

88. Waqa G, Moodie M, Schultz J, Swinburn B. Process evaluation of a community-based intervention program: Healthy Youth Healthy Communities, an adolescent obesity prevention project in Fiji. Glob Health Promot. 2013; 20(4):23-34. doi: https://doi.org/10.1177/1757975913501909

89. Sebire SJ, Edwards MJ, Kesten JM, May T, Banfield $\mathrm{KJ}$, Bird EL, et al. Process evaluation of the Bristol girls 
dance project. BMC Public Health. 2016; 16:349. doi: https://doi.org/10.1186/s12889-016-3010-4

90. Kheirouri S, Alizadeh M. Process evaluation of a national school-based iron supplementation program for adolescent girls in Iran. BMC Public Health. 2014; 14:959. doi: https://doi.org/10.1186/1471-2458-14-959

91. Al-Iryani B, Basaleem H, Al-Sakkaf K, Kok G, Borne BVD. Process evaluation of school-based peer education for HIV prevention among Yemeni adolescentes. SAHARA J. 2013; 10(1):55-64. doi: https://doi.org/10.1080/17290376.2012.745294

92. Stubbs BW, Panozzo CA, Moss JL, Reiter $\mathrm{PL}$, Whitesell DH, Brewer NT. Evaluation of an intervention providing HPV vaccine in schools. Am J Health Behav. 2014; 38(1):92-102. doi: https://doi.org/10.5993/AJHB.38.1.10

93. Montenegro E, Salinas J, Parra M, Lera L, Vio F. Evaluation of a nutrition education intervention in teachers and students in preschool and primary schools in los Andes, Chile. Arch Latinoam Nutr. [Internet]. 2014 [cited Jul 29, 2017];64(3):182-91. Available from: https://www.ncbi.nlm.nih.gov/pubmed/26137794

94. Bannink R, Broeren S, Heydelberg J, Klooster E, Baar C, Raat H. Your Health, an intervention at senior vocational schools to promote adolescents' health and health behaviors. Health Educ Res. 2014; 29(5):773-85. doi: https://doi.org/10.1093/her/cyu038

95. Parsons WG, Garcia GM, Hoffman PK. Evaluating School Wellness Policy in Curbing Childhood Obesity in Anchorage, Alaska. J Sch Nurs. 2013; 30(5):324-11. doi: https://doi.org/10.1177/1059840513513155

96. Melnyk MB, Kelly S, LusK P. Outcomes and Feasibility of a Manualized Cognitive-Behavioral Skills Building Intervention: Group COPE for Depressed and Anxious Adolescents in School Settings. J Child Adolesc Psychiatr Nurs. 2014; 27(1):3-13. doi: https://doi.org/10.1111/jcap.12058

97. Konishi C, Saewyc E, Homma Y, Poon C. Populationlevel evaluation of school-based interventions to prevent problem substance use among gay, lesbian and bisexual adolescentsin Canada. PrevMed.2013; 57(6):929-33.doi: https://dx.doi.org/10.1016\%2Fj.ypmed.2013.06.031 98. Lehna C, Todd JA, Keller R, Presley L, Jackson J, Davis $S$ et al. Nursing students practice primary fire prevention. Burns. 2013; 39(6):1277-84. doi: http://dx.doi.org/10.1016/j.burns.2013.01.016

99. Mmbaga EJ, Kajula L, Aaro LE, Kilonzo M, Wubs AG, Eggers SM, et al. Effect of the PREPARE intervention on sexual initiation and condom use among adolescents aged 12-4: a cluster randomised controlled trial in Dar es Salaam, Tanzania. BMC Public Health. 2017; 17:322. doi: https://doi.org/10.1186/s12889-017-4245-4 100. Kiviruusu O, Björklund $\mathrm{K}$, Koskinen $\mathrm{HL}$, Liski A, Lindblom J, Kuoppamäki $\mathrm{H}$ et al. Short-term effects of the "Together at School" intervention program on children's socio-emotional skills: a cluster randomized controlled trial. BMC Psychol. 2016; 4(1):27. doi: https://doi.org/10.1186/s40359-016-0133-4

101. Gunawardena N, Kurotani K, Indrawansa S, Nonaka D, Mizoue T, Samarasinghe D. Schoolbased intervention to enable school children to act as change agents on weight, physical activity and diet of their mothers: a cluster randomized controlled trial. Int J Behav Nutr Phys Act. 2016; 13:45. doi: https://doi.org/10.1186/s12966-016-0369-7

102. Bavarian N, Lewis KM, Acock A, DuBois DL, Yan $Z$, Vuchinich S, et al. Effects of a School-Based SocialEmotional and Character Development Program on Health Behaviors: A Matched-Pair, Cluster-Randomized Controlled Trial. J Prim Prev. 2016; 37(1):87-105. doi: https://doi.org/10.1007/s10935-016-0417-8

103. Heo $M$, Irvin $E$, Ostrovsky $N$, Isasi C, Blank AE, Lounsbury DW, et al. Behaviors and Knowledge of HealthCorps New York City High School Students: Nutrition, Mental Health, and Physical Activity. J Sch Health. 2016; 86(2):84-95. doi: http://dx.doi.org/10.1111/josh.12355

104. Dahlqvist HZ, Landstedt E, Gådin KG. What students do schools allocate to a cognitive-behavioural intervention? Characteristics of adolescent participants in Northern Sweden. Int J Circumpolar Health. 2015; 74:10. doi: http://dx.doi.org/10.3402/ijch.v74.29805

105. Tahlil T, Woodman RJ, Coveney J, Ward PR. Six-months follow-up of a cluster randomized trial of school-based smoking prevention education programs in Aceh, Indonesia. BMC Public Health. 2015; 15:1088. doi: https://doi.org/10.1186/s12889-015-2428-4

106. Serafini K, Shipley L, Stewart DG. Motivation and substance use outcomes among adolescents in a schoolbased intervention. Addict Behav. 2015; 53:74-9. doi: https://doi.org/10.1016/j.addbeh.2015.10.004

107. Glang AE, Koester MC, Chesnutt JC, Gioia GA, McAvoy K, Marshall S et al. The effectiveness of a webbased resource in improving postconcussion management in high schools. J Adolesc Health. 2015; 56(1):91-7. doi: http://dx.doi.org/10.1016/j.jadohealth.2014.08.011

108. Marsiglia FF, Kulis SS, Booth JM, NuñoGutierrez BL, Robbins DE. Long-term effects of the keepin' it REAL model program in Mexico: substance use trajectories of Guadalajara middle school students. J Prim Prev. 2015; 36(2):93-104. doi: http://dx.doi.org/10.1007/s10935-014-0380-1

109. Kobel S, Wirt T, Schreiber A, Kesztyüs D, Kettner $\mathrm{S}$, Erkelenz $\mathrm{N}$, et al. Intervention effects of a school-based health promotion programme on obesity related behavioural outcomes. J Obes. 2014; 24:185-92. doi: http://dx.doi.org/10.1155/2014/476230 
110. Sharpe H, Schober I, Treasure J, Schmidt U. Feasibility, acceptability and efficacy of a school-based prevention programme for eating disorders: cluster randomised controlled trial. $\mathrm{Br} \mathrm{J}$ Psychiatry. 2013; 203(6):428-35. doi: http://dx.doi.org/10.1192/bjp.bp.113.128199

111. Gesell SB, Sommer EC, Lambert EW, Vides AAR, Whitaker $L$, Davis $L$, et al. Comparative effectiveness of after-school programs to increase physical activity. J Obes. 2013; 2013:576821. doi: http://dx.doi.org/10.1155/2013/576821

112. Andrews JA, Gordon JS, Hampson SH, Gunn $B$, Christiansen SM, Slovic P. Long-term efficacy of click city( $r)$ : tobacco: a school-based tobacco prevention program. Nicotine Tob Res. 2014; 16(1):33-41. doi: https://doi.org/10.1093/ntr/ntt106

113. Standage $M$, Cumming SP, Gillison FB. A cluster randomized controlled trial of the be the best you can be intervention: effectson thepsychological and physical wellbeing of school children. BMC Public Health. 2013; 13:666. doi: https://doi.org/10.1186/1471-2458-13-666

114. McNaughton DB, Cowell JM, Fogg L. Adaptation and feasibility of a communication intervention for Mexican immigrant mothers and children in a school setting. J Sch Nurs. 2014; 30(2):103-13. doi: http://dx.doi.org/doi:10.1177/1059840513487217 115. Tahlil T, Woodman RJ, Coveney J, Ward PR. The impact of education programs on smoking prevention: a randomized controlled trial among 11 to 14 year olds in Aceh, Indonesia. BMC Public Health. 2013; 13:367. doi: https://doi.org/10.1186/1471-2458-13-367

116. Monse B, Benzian $H$, Naliponguit $E$, Belizario V, Schratz A, Van PHW. The Fit for School Health Outcome Study - a longitudinal survey to assess health impacts of an integrated school health programme in the Philippines. BMC Public Health. 2013; 13:256. doi: https://doi.org/10.1186/1471-2458-13-256

117. Kyle RG, Forbat L, Rauchhaus P, Hubbard G. Increased cancer awareness among British adolescents after a school-based educational intervention: a controlled before-and-after study with 6-month follow-up. BMC Public Health. 2013; 13:190. doi: https://doi.org/10.1186/1471-2458-13-190

118. Minary $L$, Cambon L, Martini $H$, Wirth N, Acouetey DS, Thouvenot F, et al. Efficacy of a smoking cessation program in a population of adolescent smokers in vocational schools: a public health evaluative controlled study. BMC Public Health. 2013; 13:149. doi: https://doi.org/10.1186/1471-2458-13-149

119. Schneider M, DeBar L, Calingo A, Hall W, Hindes $K$, Sleigh A, et al. The effect of a communications campaign on middle school students' nutrition and physical activity: results of the HEALTHY study. J Health Commun. 2013; 18(6):649-67. doi: http://dx.doi.org/10.1080/10810730.2012.743627

120. Pbert L, Druker S, Gapinski MA, Gellar L, Magner R, Reed G, et al. A school nursedelivered intervention for overweight and obese adolescents. J Sch Health. 2013; 83(3):182-93. doi: http://dx.doi.org/10.1111/josh.12014

121. Safdie M, Lévesque L, González CI, Salvo D, Islas A, Hernández CS, et al. Promoting healthful diet and physical activity in the Mexican school system for the prevention of obesity in children. Salud Publica Mex. [Internet]. 2013 [cited Jul 29, 2017];55(3):357-63. Available from: http://www.scielosp.org/pdf/spm/v55s3/v55s3a3.pdf

122. Zhang C, Mosa AJ, Hayward AS, Matthews SA. Promoting clean hands among children in Uganda: a school-based intervention using 'tippy-taps'. Public Health. 2013; 127(6):586-9. doi: http://dx.doi.org/10.1016/j.puhe.2012.10.020

123. Oscós-Sánchez MÁ, Lesser J, OscósFlores LD. High school students in a health career promotion program report fewer acts of aggression and violence. J Adolesc Health. 2013; 52(1):96-101. doi: http://dx.doi.org/10.1016/j.jadohealth.2012.04.006 124. Isensee B, Hansen J, Maruska K, Hanewinkel $R$. Effects of a school-based prevention programme on smoking in early adolescence: a 6-month follow-up of the 'Eigenstandig werden' cluster randomised trial. BMJ Open. [Internet]. 2016 [cited Jul 29, 2017];39(3):336-5. Available from: http://journals.sagepub.com/doi/ pdf/10.1177/0163278715588825

125. Cunningham-Sabo L, Lohse B. Cooking with Kids positively affects fourth graders' vegetable preferences and attitudes and self-efficacy for food and cooking. Child Obes. 2013; 9(6):549-56. doi: https://doi.org/10.1089/chi.2013.0076

126. Kansagra SM, Papadouka V, Geevarughese A, Hansen MA, Konty KJ, Zucker JR. Reaching children never previously vaccinated for influenza through a school-located vaccination program. Am J Public Health. 2014; 104(1):45-9. doi: http://dx.doi.org/10.2105/AJPH.2013.301671

127. Ramos P, Pasarín MI, Artazcoz L, Díez E, Juárez O, González I. Healthy and participative schools: evaluation of a public health strategy. Gac Sanit. 2013; 27(2):104-10. doi: http://dx.doi.org/10.1016/j.gaceta.2012.04.002

128. Alvirde $\mathrm{U}$, Aguilar SCA, Gómez PFJ, Henao MS, Rodríguez AJG. Results of a community based life style intervention program for children. Salud Publica Mex. [Internet]. 2013 [cited Jul 29, 2017];55(3)406-14. Available from: http://www.scielosp.org/pdf/spm/v55s3/v55s3a7.pdf 129. Serowoky, ML, George N, Yarandi H. Using the Program Logic Model to Evaluate iCuídate! : A Sexual Health 
Program for Latino Adolescents in a School-Based Health Center. Worldviews Evid Based Nurs. 2015; 12(5):297-305. doi: http://dx.doi.org/10.1111/wvn.12110

130. Nabors L, Burbage M, Woodson KD, Swoboda C. Implementation of an after-school obesity prevention program: helping young children toward improved health. Issues Compr Pediatr Nurs. 2015; 38(1):22-38. doi: http://dx.doi.org/10.3109/01460862.2014.973081 131. Sidhu AK, Sussman S, Tewari A, Bassi S, Arora M. Project EX-India: A classroombased tobacco use prevention and cessation intervention program. Addict Behav. 2016; 53:53-7. doi: https://doi.org/10.1016/j.addbeh.2015.09.005

132. Biddle VS, Kern J, Brent DA, Thurkettle MA, Puskar $K R$, Sekula $L$, et al. Student assistance program outcomes for students at risk for suicide. J Sch Nurs. 2014; 30(3):173-86. doi: http://dx.doi.org/10.1177/1059840514525968

133. Primack BA, Douglas EL, Land SR, Miller E, Fine MJ. Comparison of media literacy and usual education to prevent tobacco use: a clusterrandomized trial. J Sch Health. 2014; 84(2):106-15. doi: http://dx.doi.org/10.1111/josh.12130

134. Sussman AL, Montoya C, Werder O, Davis S, Wallerstein N, Kong AS. Evaluation of an intervention providing HPV vaccine in schools. Am J Health Behav. 2014; 38(1):92-102. doi: https://doi.org/10.5993/AJHB.38.1.10

135. Drubin DG, Kellogg DR. English as the universal language of science: opportunities and challenges. Mol Biol Cell. 2012; 23(8):1399. doi: https://doi.org/10.1091/mbc.E12-02-0108

136. Tanaka OY, Tamaki EM. The role of evaluation in decision-making in the management of health services. Cien Saúde Coletiva. 2012 Apr; 17(4):821-8. doi: http://dx.doi.org/10.1590/S1413-81232012000400002 137. Brousselle A, Champagne F. Program theory evaluation: Logic analysis. Eval Program Plann. 2011 Feb; 34(1):69-78. doi: https://doi.org/10.1016/j.evalprogplan.2010.04.001

138. Furtado JP, Vieira-da-Silva LM. The evaluation of health programs and services in Brazil as a space for knowledge and practice. Cad Saúde Pública. 2014 Dec; 30(12):2643-55. doi: http://dx.doi.org/10.1590/0102-311X00187113
139. Viacava F, Ugá MAD, Porto S, Laguardia J, Moreira RS. Evaluation of performance of health systems: a model for analysis. Cienc Saúde Coletiva. 2012 Apr; 17(4):921-34. doi: http://dx.doi.org/10.1590/S1413-81232012000400014 140. McIsaac J-LD, Penney TL, Ata N, MunroSigfridson L, Cunningham J, Veugelers PJ, et al. Evaluation of a health promoting schools program in a school board in Nova Scotia, Canada. Prev Med Rep. 2017; 5:279-84. doi: https://doi.org/10.1016/j.pmedr.2017.01.008

141. Langford R, Bonell C, Jones H, Pouliou T, Murphy $S$, Waters $E$, et al. The World Health Organization's Health Promoting Schools framework: a Cochrane systematic reviewandmeta-analysis. BMCPublicHealth. 2015; 15:130. doi: https://doi.org/10.1186/s12889-015-1360-y

142. Kontak JCH, McIsaac J-LD, Penney TL, Kuhle S, Kirk SFL. The picture of health: examining school-based health environments through photographs. Health Promot Int. 2017; 32(2):322-30. doi: https://doi.org/10.1093/heapro/daw027
Received: Aug 26th 2017 Accepted: Jan 04th 2018
Corresponding Author:

Eliabe Rodrigues de Medeiros

Universidade Federal do Rio Grande do Norte. Departamento de Enfermagem

Campus Universitário, $\mathrm{s} / \mathrm{n}$

Bairro: Lagoa Nova

CEP: 59078-970, Natal, RN, Brasil

E-mail: eliabe.medeiros@hotmail.com
Copyright $\odot 2018$ Revista Latino-Americana de Enfermagem This is an Open Access article distributed under the terms of the Creative Commons (CC BY).

This license lets others distribute, remix, tweak, and build upon your work, even commercially, as long as they credit you for the original creation. This is the most accommodating of licenses offered. Recommended for maximum dissemination and use of licensed materials. 